\begin{tabular}{c} 
Review of \\
ECONOMICS \\
and \\
INSTITUTIONS \\
\hline
\end{tabular}

\title{
Institutions, Finance and the Level of Development: the Impact on Entrepreneurship in Transition
}

\author{
Ruta Aidis \\ University College London
}

\author{
Saul Estrin \\ London School of \\ Economics
}

\author{
Tomasz Mickiewicz ${ }^{\bowtie}$ \\ University College London
}

\begin{abstract}
We investigate the impact of institutions on entrepreneurial entry, based on a large cross-country sample, combining working age population data generated by the GEM project with macro level indicators. Our four key findings indicate that: (a) institutional obstacles to entrepreneurship have different impact in rich countries compared to poor countries; (b) institutional obstacles have a stronger impact on 'opportunity entrepreneurship' than on 'necessity entrepreneurship'; (c) two institutional indicators - property right protection and access to finance - appear to have a dominant impact on entrepreneurship; (d) institutions have a long term impact. More than ten years after the Soviet system imploded in Central and Eastern Europe, these countries still experience significantly lower levels of entrepreneurship than economies coming from different legal traditions.
\end{abstract}

JEL classification: L26, P14, P51, P37

Keywords: entrepreneurship, property rights, access to finance

\section{Introduction}

Existing studies indicate that the entry of new firms can result in employment creation and more equitable income distributions. New firm entry provides a churning effect to the economy, fosters development, innovation and economic change (Hirschman, 1958; Baumol, 1990; McMillan and Woodruff, 2002; Mickiewicz et al., 2005; Berkovitz and Jackson, 2006; Klapper et al., 2006). However, where institutions are weak entrepreneurs either do not undertake new projects or restrict their

${ }^{\square}$ Corresponding author. Address: Department of Social Sciences, School of Slavonic and East European Studies, UCL, Gower St, London, WC1E 6BT. (Phone: +44-20-76798757, Fax: ; +44-20-76798777; Email: t.mickiewicz@ucl.ac.uk)

\section{Recommended Citation}

Aidis, R., Estrin, S., Mickiewicz, T. (2010). Institutions, Finance and the Level of Development: the Impact on Entrepreneurship in Transition. Review of Economics and Institutions, 1 (1), Article 3. doi: 10.5202/rei.v1i1.3. Retrieved from http://www.rei.unipg.it/rei/article/view/3 
activities to unproductive ones, with a resulting loss of efficiency (Glaeser et al., 2003; Johnson et al., 1997; Baumol, 1990). Unfortunately, institutions are difficult to measure and unbundle. As a result, the challenge of exploring the link between institutions and entrepreneurship has rarely been analysed successfully in the empirical literature. In this paper, we attempt to address this knowledge gap.

One of the major reasons limiting the existing empirical literature is the shortage of appropriate comparative data. Most studies on entrepreneurship focus on small enterprises, taking them as a proxy for entrepreneurial activity. Yet, to study the issue of entry one has to have data on the whole universe of potential entrepreneurs, not just of the existing business owners. We base our understanding of entrepreneurship on the work of Lumpkin and Dess who state that the essential act of entrepreneurship is new entry' (1996, p. 136). Moreover, we differentiate between different types of entrepreneurship in terms of the entrepreneur's motivation being driven by entrepreneurial opportunity or necessity. Data collected through the Global Entrepreneurship Monitor (GEM) surveys, an international project co-ordinated jointly by Babson College, USA and London Business School, UK, offers a unique opportunity to analyse entrepreneurs within the context of the working age population. Another important advantage of using the GEM dataset is that one can safely introduce the institutional country-level variables (proxies) as explanatory factors, without being concerned with simultaneity bias (as the individual decision of a potential entrepreneur does not affect countrylevel institutions). As argued by Schaffer et al. (2006), business barriers (in our case: obstacles to entry) can be best tested using cross-country variation and this is made possible through the GEM dataset. We use the rich data available in the GEM 2001-2005 surveys to analyse the institutional barriers to entrepreneurship. Much analysis have already been undertaken using GEM data at a country level and some limited studies have compared countries' aggregate indicators, but we are not aware of any study which has investigated the impact of institutions on entrepreneurship, combining macro and micro level data.

This study is also novel in its institutional approach. We apply an institutional framework in order to analyse the effects of the institutional environment on entrepreneurship development in 31 different countries taking special care of multicollinearity between the institutional indicators. While researchers such as Desai et al. (2003) and Klapper et al. (2006) have used other datasets and Wennekers et al. (2005) have used country level means from the GEM dataset to analyse similar issues, we would argue that our work presents a more comprehensive study both in terms of scope, scale and methodology and therefore offers more robust results. 
Our four key findings indicate that: (a) institutional obstacles to entrepreneurship have different impact in rich countries compared to poor countries; (b) institutional obstacles have a stronger impact on 'opportunity entrepreneurship' than on 'necessity entrepreneurship'; (c) two institutional indicators - property right protection and access to finance - appear to have a dominant impact on entrepreneurship; (d) institutions have a long term impact. More than ten years after the Soviet system imploded in Central and Eastern Europe, these countries still experience significantly lower levels of entrepreneurship than economies coming from different legal traditions.

This paper is structured as follows. Section 2 presents our institutional framework and develops the four hypotheses to be tested. Section 3 provides a description of the data used, the variables chosen for our analysis as well as an overview of the estimation techniques employed. Section 4 presents our results and the paper concludes in section 5 .

\section{Hypotheses}

Our hypotheses are derived from applying an institutional framework to the issue of entrepreneurship development in a cross-cultural context. We focus on the effect of institutions on entrepreneurship entry. We expect that when considering entry, potential entrepreneurs will take into account both direct barriers encountered at time of entry and continuous constraints in the business environment.

Therefore, our first hypothesis is:

H1: The level of entrepreneurial entry will be higher as both the business environment (institutions) improves and the entry costs are lower.

In line with the four studies discussed above, in a study based on entrepreneurship based on transition countries in Eastern Europe, Johnson et al. (2002) find that the insecurity of property rights may be a key factor deterring entry in the small firm sector. North has argued that insecure property rights result in using technologies that employ little fixed capital and that firms will typically be small (North 1990, p. 65). Grilo and Irigoyen (2006) report a negative effect of the perception of lack of finance on the probability of being self-employed using European data for 2000, though Grilo and Thurik (2005) are unable to identify an effect for 2004. Studies mentioned above indicate the protection of property rights and finance may present two crucial institutional characteristics affecting the entrepreneurship entry. We formulate our second hypothesis to read:

H2: Property rights and finance are the two institutional characteristics that have most significant effect on the level of entrepreneurial activity. 
In line with the existing literature (such as Wennekers et al., 2005), we expect institutional legacies to persist. As a result, legal origin should matter. In particular, we expect that countries emerging from the Soviet system may still suffer from the 'entrepreneurial deficit':

H3: Institutional legacies will affect entrepreneurial activity resulting in countries emerging from the Soviet system to suffer lower levels of entrepreneurial activity.

There is general agreement in the field of entrepreneurship that the whole notion of entrepreneurship hinges on the concept of opportunity recognition (McMullen and Sheperd, 2006). Entrepreneurial behaviour as such is not seen as a stable characteristic that differentiates some people from others, but as the tendency of some individuals to respond to the situation cues of opportunities (Shane and Venkataraman, 2000, p. 219). Logically, subsequent to the discovery of an opportunity, a potential entrepreneur must decide to exploit the opportunity (ibid). Individuals process the cues from the environment around them and set about constructing the perceived opportunity into a viable business proposition (Krueger et al., 2000). As Sarasvathy (2004, p. 209) notes, most individuals will become entrepreneurs due to suitable conditions; a combination of opportunity and a conducive environment. We therefore would expect individuals who are reacting to entrepreneurial opportunities in the environment to be more sensitive to the overall institutional environment (which in turn affects the attractiveness of opportunity exploitation) than individuals who become entrepreneurs purely out of necessity. Therefore hypothesis 4 has been formulated to read:

H4: The significance of institutions on the level of entrepreneurial activity will be greater for opportunity than necessity entrepreneurship.

\section{Data and Methodology}

This section provides further detail regarding the data used (collected by the Global Entrepreneurship Monitor) as well as a presentation of the independent and dependent variables used for our analysis. In addition, it describes the estimation techniques used to test our hypotheses.

\subsection{GEM Data}

The dataset we utilise was generated by the GEM project. Data are generated by surveys, which rely on stratified samples of at least 2,000 individuals per country. The dataset includes a number of individual social and economic characteristics and perceptions. The key advantage of the GEM methodology relates to the fact that the sample is drawn from the whole working age population in each country and therefore captures 
both entrepreneurs and non-entrepreneurs. While data on business ownership and individual business financing is included, entrepreneurial activity is primarily viewed as new, nascent start-up activity. Nascent entrepreneurs are those individuals between the ages of $18-64$ years who have taken some action toward creating a new business in the past year. To qualify for this category, these individuals must also expect to own a share of the business they are starting and the business must not have paid any wages or salaries for more than three months (Minniti et al., 2005b). Established entrepreneurs are defined as individuals who own or manage a company and have paid wages or salaries for more than 42 months (ibid).

We utilise all available data from the 2001-2005 surveys. Our survey database includes the following individual country samples (all have at least 2,000 observations): Argentina, Belgium, Brazil, Canada, Denmark, Finland, France, Georgia, India, Ireland, Island, Italy, Japan, Korea, Mexico, Netherlands, New Zealand, Norway, Portugal, South Africa, Sweden, United Kingdom, United States (all 2001), Slovenia (2001-2005), Hungary (2001, 2002, 2004, 2005), Poland (2001 and 2002), Spain (2001 and 2004), Australia (2001 and 2005), Russia (2002), Latvia (2005).

In our measures for the institutional environment, for methodological reasons already discussed we depart from the practice of running separate models for each institutional dimension entered alone. Instead we follow two alternative methods. Firstly, we use a single aggregate institutional indicator (corruption measure from Transparency International and economic freedom measure from Heritage). Secondly, we focus on a smaller number of indicators using the results of the exploratory factor analysis based on the Heritage Foundation's ten institutional indicators discussed above. We discuss the two methods in turn.

\subsection{Single, Aggregate Institutional Indicators: Economic Freedom, Corruption}

It is not only the direct barriers to start the business but also the barriers to develop it which count for start-up decisions. Where the potential entrepreneurs perceive that they would not be able to expand their businesses to realise all potential gains, they may decide against starting it. ${ }^{1}$ Thus, general business environment may count for entrepreneurial decisions. In this respect, the Heritage Foundation's aggregate index of economic freedom matches the type of measurements useful for the

\footnotetext{
${ }^{1}$ This is also the reason why the results on factors affecting incorporation (as discussed above) count. The forward-looking entrepreneur is likely to take opportunities for further business development in his/her decision to entry.
} 
analysis of our hypotheses. ${ }^{2}$ In our analysis, we use the Heritage Foundation's aggregate Index of Economic Freedom (based on ten institutional indicators) as our first measure to illustrate the possible effects of barriers in the institutional environment on new firm entry.

Our second aggregate measure of the institutional environment is the Corruption Perception Index, published by Transparency International. Corruption may be seen as a general proxy for the quality of the institutional environment. Tanzi (1998) argues that corruption reflects the multidimentional impact of poor institutions and Djankov et al. (2002) provides empirical evidence showing that corruption reflects an inefficient overregulated environment. Incidence of corruption may prevent business to grow above some threshold level, as in the latter case, the business owners may be expropriated by corrupt officials, especially the tax authority (Barkhatova, 2000; Aidis and Mickiewicz, 2006). Moreover, expectations of this kind may in turn discourage potential entrepreneurs from starting a business.

Transparency International index relies on a methodology which combines information from ten different surveys of corruption, where a score for any country is included only when there is an overlapping assessment of a country at least by three independent surveys. The respondents come from three different groups: residents of the developed countries familiar with a given economy, non-residents from neighbouring countries, and own-residents. The correlation in assessment between these three groups is high. The scores from different surveys are combined by first matching percentiles between surveys, correcting resulting distributions with Beta transformation and finally estimating distributions of scores for each country using bootstrapping (see Lambsdorff, 2005, for details).

\subsection{Multiple Institutional Indicators. Unbundling the Economic Freedom: Results}

We now turn to the results of our exploratory factor analysis. While the details of the analysis are presented in the next section, we first present the summary of our results, namely the four dimensions we obtained via compressing the ten indicators of the Heritage Foundation. Data reduction is needed to eliminate the impact of multicollinearity so that we can focus on the reduced number of variables characterised by an acceptable level of cross-correlation. However, where possible we will apply the underlying

2 The Heritage Foundation defines economic freedom as the absence of government coercion or constraint on the production, distribution, or consumption of goods and services beyond the extent necessary for citizens to protect and maintain liberty itself' (Beach and Miles, 2006, p. 56). 
economic indicators that correspond to the highest loadings on each factor instead of extracted factors.

In addition, we introduce a variable representing the size of the financial sector, and following Klapper et al. (2006) we use the ratio of credit to private sector to GDP as our proxy for the supply of finance in the economy.

\subsection{Unbundling the Economic Freedom: Economic Freedom or Institutional Quality?}

We now turn to the details of our data reduction exercise. A closer look at the Heritage Foundation indicators reveals possible discrepancy between what they aim to measure and what in reality is captured by the measurement instruments. While the indicators measure heterogeneity in institutions one should not assume that they can all be ordered along the same underlying axis. As confirmed by our principal components analysis (see below), the individual indicators cluster around more than one factor. Therefore, while we will apply the aggregate composite measure of economic freedom as constructed by Heritage Foundation, we also wish to explore a multivariate set of variables derived from the individual dimensions via factor analysis. The reason for the latter relates to the possible multidimensionality of the Heritage dataset. The first measure, "Restrictions in Trade Policy", may be taken as the least controversial. However, when we move to the second dimension ("fiscal burden"), the consensus vanishes. In particular, while high taxation may result in deadweight cost, there is also evidence that economic systems where extreme income and wealth inequality is not corrected by redistribution are also associated with inefficient outcomes. ${ }^{3}$ A similar argument relates to the "Government Intervention" dimension, which mixes the size of government ownership of productive assets with the scale of government consumption. While most empirical evidence points to the inefficiency of government ownership (in particular, see Megginson and Netter, 2001), there is less consensus regarding the share of government consumption of GDP. The structure of government consumption may be more important than the size.

The problem is different with the "Monetary Policy" dimension. This measure is based on inflation and does not include governmental interference in the economy, but rather the efficiency of macroeconomic

\footnotetext{
3 See for instance recent institutional analysis by Pryor (2006), who found that a combination of a relatively unrestricted business environment and equal distribution of assets is an institutional design strongly associated with macroeconomic growth performance in middle and low income countries, as exemplified primarily by South East Asian economies.
} 
policy. These two dimensions may be correlated, but need not be. Similarly, with the protection of "Property Rights", the risk of expropriation by the government illustrates just one aspect, albeit a very critical one. Equally important however is the quality of law and the efficiency of the judicial system. This may be affected negatively as much by organised crime as by a dysfunctional government. As a result, the relevant spectrum for this indicator does not necessarily indicate the difference between a liberal and an interfering government, but between an efficient and inefficient government administration. Some of the developed economies (such as in Scandinavia), which are typically associated with large government, would also have the strongest system protecting their property rights. A similar argument relates to "Informal Market Activity", which incorporates the measure of corruption. Again, the critical difference illustrated by the indicator is between efficient and inefficient law and administrative practice and not between interfering and liberal government types as the Heritage Foundation asserts.

In our opinion, while the Heritage Foundation calls its aggregate measure "Economic Freedom", it should rather be seen as a joint, composite measure of freedom from economic interference by the government and of efficiency of economic policies, administration and institutions, with a caveat that those sub-dimensions are not necessary collinear.

Keeping these caveats in mind, we unbundle the ten indicators reported by Heritage Foundation using a principal components analysis. We utilise the available dataset (11 years from 1995-2005 including 164 countries and ten indicators) available on the Heritage Foundation's website ${ }^{4}$. If we take a cut-off point of eigenvalues for factors being greater than one (Kaiser's criterion), it results in data compression with just one factor "Property Rights" playing the dominant role. Once we apply a restrictive criterion (Jolliffee's criterion: eigenvalues higher than 0.7), we produce four factors. The four factors extracted from the second exercise are reproduced in Table 1 below.

${ }^{4}$ As accessed in September 2006. 
Table 1 - Heritage Foundation Indicators. Pattern Matrix

\begin{tabular}{|c|c|c|c|c|}
\hline \multirow[t]{2}{*}{. } & \multicolumn{4}{|c|}{ Component } \\
\hline & 1 & 2 & 3 & 4 \\
\hline Property Rights & 0.937 & & & \\
\hline Regulation & 0.868 & & & \\
\hline Informal Markets & 0.812 & & & \\
\hline Foreign Investment Regulation & 0.768 & & & \\
\hline Trade Policy & 0.699 & & & \\
\hline Banking and Finance & 0.624 & & & \\
\hline Wages and Prices & 0.537 & & -0.408 & \\
\hline Fiscal Sector & & & & \\
\hline Government Intervention & & & -0.914 & \\
\hline Monetary Policy & & & & 0.927 \\
\hline
\end{tabular}

The pivotal role of the property rights dimension is a striking result. Clearly, property rights are in the centre of nexus of connections with most of other institutional features. We are also able to confirm that both 'Fiscal Burden' and 'Monetary Policy' dimensions are disconnected from other institutional factors and should be best considered separately. In other words, strong property rights do not seem to be associated with either any particular tax regime, or with any particular inflation levels. The third factor is mostly driven by "Government Intervention" (which mix government consumption share with the scale of government ownership) and to lesser extent by labour market regulation. In this case, the economic size of the government and the scope of labour regulations seem to be associated.

\subsection{Legal Origin}

Heritage Foundation measures are closely correlated with another timeinvariant institutional measure, which plays a key role in the recent empirical economic studies on institutions. This related to the issue of legal origin, originally classified by La Porta et al. (1999) into five broad categories: English, French, German, Scandinavian and Socialist (Communist). According to La Porta et al. (1999), the legal origin can be viewed as a proxy for the government's proclivity to intervene in the economy and the stance of the law toward security of property rights in a country. In light of our discussion above, it is not surprising that the English origin dimension, here seen as a benchmark, correlates closely with the summary average "Economic Freedom" indicator. This is also consistent with Djankov et al. (2002), who demonstrate that countries of French, German and Socialist legal origin have more entry regulations 
than English legal origin countries, while countries of Scandinavian legal origin have about the same. We use the legal origin categories as defined by La Porta et al. (1999) as independent variables in our analysis.

\subsection{Control Variables: Characteristics of Entrepreneurs and Economic Development}

Most research indicates that men have a higher probability of becoming entrepreneurs than women (Minniti et al., 2005a; Verheul et al., 2006). The relationship between entrepreneurship and age is typically found as nonlinear and hump-shaped, with a peak point for starting a business appearing relatively early (Levesque and Minniti, 2006). In addition, the impact of human capital is an important area of research in terms of its relationship to entrepreneurship. Delmar and Davidsson (2000) and Davidsson and Honig (2003) show a clear education effect for nascent entrepreneurs. Parker (2006) suggests that on average, entrepreneurs tend to be more educated than non- entrepreneurs. Wennekers et al. (2005) have also found a significant relationship between entrepreneurship role models and their effect on entrepreneurship start-ups. In their cross country study of nascent entrepreneurship rates in 36 countries, they found a significant and positive relationship between the number of incumbent business owners and entrepreneurial start-ups.

Research has also explored the relationship between previous employment and entrepreneurship. Storey (1994) found evidence indicating a negative relationship between being unemployed before starting a business and the likelihood of actual start-up ${ }^{5}$.

Perceptual factors may also be important. Role models may play a part, including providing information, which alleviates both uncertainty and the cost of starting the business (Minniti, 2005). In this context, contacts with other business owners may be important at the time of the decision to start-up. Finally, due to informational asymmetries that are particularly severe for new start-ups, financing and capital constraints have been identified as a major issue for potential entrepreneurs. Evans and Jovanovic (1989) show that, due to capital constraints, there is a positive relationship between the probability of becoming self-employed and the assets of the entrepreneur. Similarly, Evans and Leighton (1989) show that the exploitation of entrepreneurial opportunities is more common when people have greater financial capital. We capture some aspects of the individual specific financial constraints by using a dummy variable, which indicates if a potential entrepreneur was providing funds for business financing in the past.

\footnotetext{
${ }^{5}$ A literature review regarding the relationship between business start-up and being unemployed is discussed in Chapter 3 of Storey (1994, p. 71 - 74).
} 
A number of studies have indicated the relationship between economic development and entrepreneurship development (Wennekers et al., 2005; Carree et al., 2002; Acs et al., 1994). We control for economic development by including a measure of per capita GDP (purchasing power parity).

Definitions of all the variables and descriptive statistics are presented in Table 2.

Table 2 - Explanatory Variables

\begin{tabular}{|c|c|c|c|c|}
\hline Variables & Definition & Mean & SD & $\begin{array}{r}\text { Number of } \\
\text { Obs. }\end{array}$ \\
\hline \multicolumn{5}{|c|}{ INSTITUTIONAL VARIABLES } \\
\hline her_econfree & $\begin{array}{l}\text { Index of economic freedom (Heritage Foundation); } \\
\text { a higher score represents worse institutions }\end{array}$ & 2.42 & 0.53 & 104,112 \\
\hline ti_cpi & $\begin{array}{l}\text { Corruption perceptions index (Transparency } \\
\text { International); higher score represents less } \\
\text { corruption (i.e. better institutions) }\end{array}$ & 6.43 & 1.97 & 104,112 \\
\hline pro_strong & $\begin{array}{l}1=\text { Heritage Foundation 'Property Rights' index has } \\
\text { a value of one (strongest), zero otherwise }\end{array}$ & 0.41 & 0.49 & 104,112 \\
\hline credit_pri & $\begin{array}{l}\text { ratio of credit to the private sector to GDP (source: } \\
\text { WB WDI) }\end{array}$ & 82.74 & 47.13 & 104,112 \\
\hline inf_stdev & $\begin{array}{l}\text { Standard deviation in inflation over last } 5 \text { years } \\
\text { (computed using WB WDI) }\end{array}$ & 2.82 & 5.62 & 104,112 \\
\hline gov_cons & Ratio of government consumption to GDP (WB WDI) & 17.66 & 4.04 & 104,112 \\
\hline tax_rate & $\begin{array}{l}\text { Highest marginal tax rate imposed on individual } \\
\text { incomes (WB WDI) }\end{array}$ & 40.22 & 9.71 & 104,112 \\
\hline \multicolumn{5}{|c|}{ LEGAL ORIGIN VARIABLES } \\
\hline English* & 1 = English legal origin, zero otherwise. & 0.29 & 0.45 & 104,112 \\
\hline French* & 1 = French legal origin, zero otherwise. & 0.25 & 0.43 & 104,112 \\
\hline German* & 1 = German legal origin, zero otherwise & 0.11 & 0.31 & 104,112 \\
\hline Scandin* & 1 = Scandinavian legal origin, zero otherwise & 0.07 & 0.25 & 104,112 \\
\hline Socialist* & $1=$ Socialist legal origin** , zero otherwise. & 0.29 & 0.45 & 104,112 \\
\hline \multicolumn{5}{|c|}{ CONTROL VARIABLES: PERSONAL CHARACTERISTICS } \\
\hline dgender & 1 = male, zero otherwise. & 0.48 & 0.50 & 104,112 \\
\hline dumownmge & $\begin{array}{l}1 \text { = current owner/manager of business, zero } \\
\text { otherwise. }\end{array}$ & 0.10 & 0.30 & 104,112 \\
\hline dumbusang & $\begin{array}{l}1=\text { business angel in past three years, zero } \\
\text { otherwise. }\end{array}$ & 0.02 & 0.15 & 103,546 \\
\hline dumknowent & $\begin{array}{l}1=\text { personally knows entrepreneur(s) in past two } \\
\text { years, zero otherwise. }\end{array}$ & 0.33 & 0.47 & 97,443 \\
\hline dumgemwork & $\begin{array}{l}1=\text { respondent is either in full time or part time } \\
\text { employment, zero otherwise. }\end{array}$ & 0.51 & 0.50 & 98,685 \\
\hline ed_postsec_high & $\begin{array}{l}1=\text { respondent has a post-secondary or higher } \\
\text { educational attainment, zero otherwise. }\end{array}$ & 0.38 & 0.48 & 98,906 \\
\hline ed_high & $1=$ respondent has a higher educational attainment & 0.14 & 0.35 & 98,906 \\
\hline age & $\begin{array}{l}\text { The exact age of the respondent at time of } \\
\text { interview }\end{array}$ & 42.83 & 16.35 & 100,110 \\
\hline age2 & Age squared & & & 100,110 \\
\hline
\end{tabular}

Table continues on next page 
Table 2- Continued

\begin{tabular}{|c|c|c|c|c|}
\hline Variables & Definition & Mean & SD & $\begin{array}{r}\begin{array}{r}\text { Number of } \\
\text { Obs. }\end{array} \\
\end{array}$ \\
\hline \multicolumn{5}{|c|}{ CONTROL VARIABLES: MEASURING ECONOMIC DEVELOPMENT } \\
\hline gdp_pc_ppp & $\begin{array}{l}\text { Measured as GDP per capita, purchasing power } \\
\text { parity, constant at } 2000 \$ \text { USD***. } 2005 \text { figures are } \\
\text { estimates based on } 2005 \text { real GDP growth rates } \\
\text { and } 2005 \text { population figures. }\end{array}$ & 20,209 & 7892,0 & 104,112 \\
\hline gdppc_ecfree & $\begin{array}{l}\text { An interactive term for gdp per capita and the Index } \\
\text { of Economic Freedom }\end{array}$ & & & \\
\hline ti_gdp & $\begin{array}{l}\text { An interactive term for gdp per capita and the } \\
\text { Corruption Perceptions Index }\end{array}$ & & & \\
\hline
\end{tabular}

\subsection{Dependent Variables: Measuring Types of Entrepreneurship}

In addition to identifying new firm entry in terms of nascent entrepreneurs ( $9 \%$ of the sample), the GEM study has identified two main reasons motivating individuals to start a firm. They are either motivated by a perceived business opportunity (opportunity entrepreneurs) or pushed into entrepreneurship because all other options for work are either absent or unsatisfactory (Minniti et al., 2005b). ${ }^{6}$ According to the results of the GEM (Minniti , 2005; Acs et al., 2004), the vast majority of early-stage entrepreneurs across the world claim that they are attempting to take advantage of a business opportunity. However some important variations are worth noting. The GEM study indicates that individuals living in countries with a diversified labour market and comprehensive unemployment care are more likely to be driven by opportunity vs. necessity motives than in countries where these institutions are weaker. Not surprisingly, the ratio of opportunity to necessity based motives for starting a business is more favourable in high-income countries rather than in middle or low income countries. Correspondingly, countries with relatively low income and low levels of social security such as China, Brazil or South Africa, tend to exhibit higher levels of necessity entrepreneurs. Since countries that primarily exhibit opportunity-driven entrepreneurship show a lower share of early-stage business failures, it seems to indicate that people starting necessity-driven businesses tend to do so due to lack of viable alternatives and under conditions that are not

\footnotetext{
${ }^{6}$ Some authors have challenged the static distinction between opportunity and necessity entrepreneurs especially in certain socio-economic contexts (such as transition countries) since entrepreneurship by definition represents a dynamic process in which individuals may change their motivation from necessity to opportunity and vice versa due to changes in personal as well as environmental circumstances (for further discussion see also Aidis et al., 2007).
} 
very favourable for business success (Minniti et al., 2005b). This latter observation leads us to notice that perceived opportunities are also related to the extent of barriers in institutional environment. Where potential entrepreneurs perceive that they may not be able to realise all the benefits from the newly created business, they may decide against starting them. This should relate far more strongly to opportunity entrepreneurship than to necessity entrepreneurship.

\subsection{Specifications and Estimation Technique}

In our analysis, we use the following models. Each of them takes the same set of individual level variables, as given above. Model 1 corresponds to the binary choice between start-up and no entrepreneurial activity. No institutional variables are included, and instead we use a full set of dummies representing each country-year sample. In model 2, the country-year dummies are replaced by the country level variables, where the index of economic freedom is taken as an aggregate proxy for the institutional heterogeneity. In model 3 the index of economic freedom is replaced by the legal origin dummies, which are strongly correlated with the former (with the following ordering: "English" = most free, next "German", "Scandinavian" and "French" close to each other, and finally "Socialist"). In model 4, the corruption perception index is used as a proxy for institutional heterogeneity. Results are presented in Tables 3 and 4.

Table 3 - Determinants of Nascent Entrepreneurship (Startup). Logistic Regression. Model 1

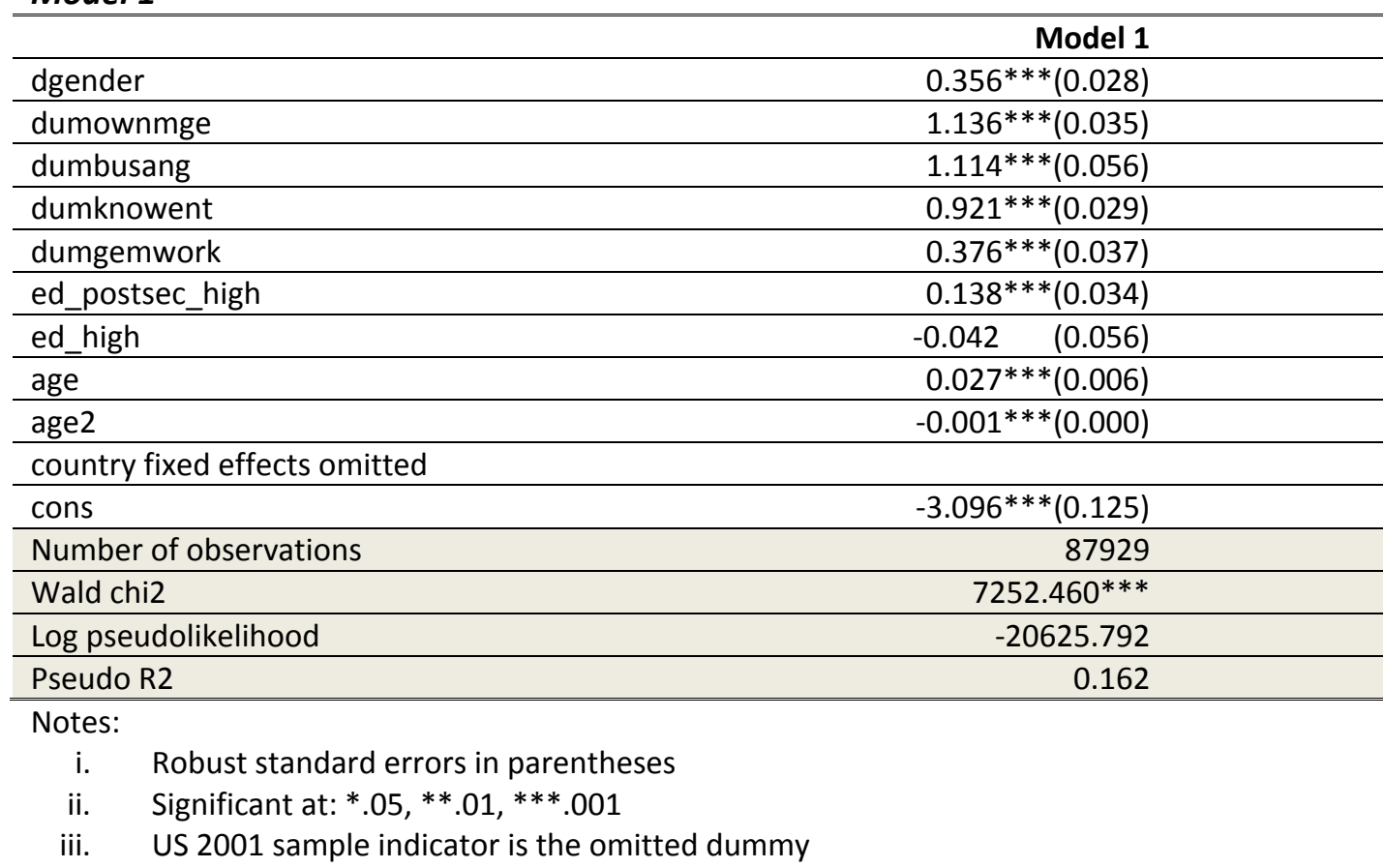


Table 4 - Determinants of Nascent Entrepreneurship (Startup). Logistic Regression. Models 2-4.

\begin{tabular}{|c|c|c|c|}
\hline & Model 2 & Model 3 & Model 4 \\
\hline dgender & $0.317 * * *(0.058)$ & $0.296 * * *(0.061)$ & $0.309 * * *(0.057)$ \\
\hline dumownmge & $1.155 * * *(0.112)$ & $1.140 * * *(0.112)$ & $1.143 * * *(0.109)$ \\
\hline dumbusang & $1.131 * * *(0.071)$ & $1.128 * * *(0.078)$ & $1.127 * * *(0.068)$ \\
\hline dumknowent & $0.915 * * *(0.057)$ & $0.957 * * *(0.060)$ & $0.890 * * *(0.055)$ \\
\hline dumgemwork & $0.295^{*} \quad(0.144)$ & $0.398 * *(0.146)$ & $0.408 * *(0.154)$ \\
\hline ed_postsec_high & $0.180 * * \quad(0.059)$ & $0.131 * \quad(0.056)$ & $0.164 * *(0.058)$ \\
\hline ed_high & $0.552 * \quad(0.216)$ & $0.401+\quad(0.232)$ & $0.587 * *(0.209)$ \\
\hline age & $(0.023)$ & $(0.021)$ & $(0.023)$ \\
\hline age2 & $-0.000 \quad(0.000)$ & $(0.000)$ & $(0.000)$ \\
\hline gdp_pc_ppp & $0.000 * * \quad(0.000)$ & $-0.000 * \quad(0.000)$ & $-0.000 * \quad(0.000)$ \\
\hline her_econfree & $0.563+\quad(0.343)$ & & \\
\hline gdppc_ecfree & $-0.000 * * *(0.000)$ & & \\
\hline socialist & & $-1.017 * * *(0.173)$ & \\
\hline german & & $-0.363 \quad(0.230)$ & \\
\hline french & & $-0.483^{*} \quad(0.234)$ & \\
\hline scandin & & $(0.364)$ & \\
\hline ti_cpi & & & $-0.203 \quad(0.177)$ \\
\hline ti_gdp & & & $0.000 \quad(0.000)$ \\
\hline cons & $-4.637 * * *(1.176)$ & $-2.751 * * *(0.357)$ & $-2.167 \quad(0.679)$ \\
\hline Number of obs & 87929 & 87929 & 87929 \\
\hline Wald chi2 & $1388.860 * * *$ & $1394.290 * * *$ & $1689.270 * * *$ \\
\hline Log pseudolikelihood & -21461.663 & -21261.638 & -21556.905 \\
\hline Pseudo R2 & 0.128 & 0.136 & 0.124 \\
\hline
\end{tabular}

Notes:

i. Robust standard errors in parentheses

ii. Significant at: †.10,*.05,**.01,***.001

iii. Std. Err. adjusted for 40 clusters in country_year

Next, in models 5 and 6 we split the dependent into 'opportunity' and 'necessity' start-ups. For each of these cross-sections we use the same explanatory set of variables, as in models 2 and 3 (i.e., with alternative measures of institutions). These results are reported in Table 5 below. 
Table 5 - Determinants of Nascent Entrepreneurship (su_opp_nec). Multinominal Logistic regression. Models 5-6.

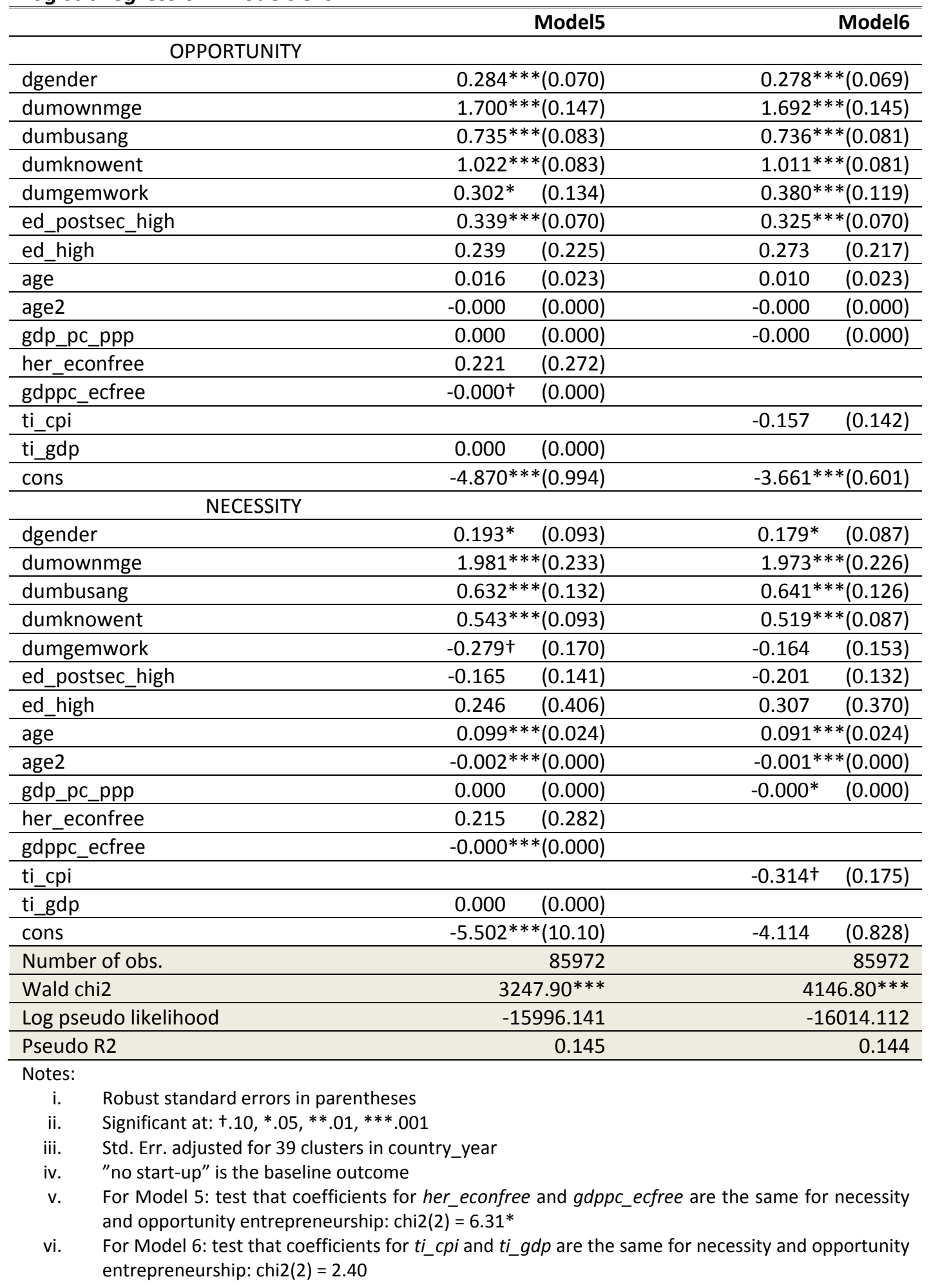


In our second set of models we move from single aggregate indices of institutional heterogeneity to multiple indicators, as discussed above. Model 7-9 report three different specifications based on combinations of individual indices (Table 6 below).

Table 6 - Determinants of Nascent Entrepreneurship (Startup). Logistic Regression. Models 7-9.

\begin{tabular}{|c|c|c|c|}
\hline & Model7 & Model8 & Model9 \\
\hline dgender & $0.302 * * *(0.058)$ & $0.304 * * *(0.059)$ & $0.303 * * *(0.060)$ \\
\hline dumownmge & $1.145 * * *(0.116)$ & $1.143 * * *(0.118)$ & $1.146 * * *(0.117)$ \\
\hline dumbusang & $1.143 * * *(0.076)$ & $1.139 * * *(0.075)$ & $1.143 * * *(0.075)$ \\
\hline dumknowent & $0.922 * * *(0.066)$ & $0.923 * * *(0.065)$ & $0.922 * * *(0.066)$ \\
\hline dumgemwork & $0.356 * \quad(0.140)$ & $0.351 * \quad(0.139)$ & $0.355^{*} \quad(0.142)$ \\
\hline ed_postsec_high & $0.192 * * *(0.055)$ & $0.197 * * *(0.061)$ & $0.192 * * *(0.056)$ \\
\hline ed_high & $(0.296)$ & $(0.275)$ & $(0.295)$ \\
\hline age & $(0.022)$ & $(0.022)$ & $(0.022)$ \\
\hline age2 & $(0.000)$ & $(0.000)$ & $(0.000)$ \\
\hline pro_strong & $0.465^{*} \quad(0.231)$ & $0.417 \dagger \quad(0.239)$ & $0.462 * \quad(0.230)$ \\
\hline credit_pri & $0.005 t \quad(0.003)$ & $0.005 * \quad(0.002)$ & $0.005+\quad(0.003)$ \\
\hline inf_stdev & $(0.029)$ & & \\
\hline gov_cons & & $(0.022)$ & \\
\hline gdp_pc_ppp & $-0.000 * * *(0.000)$ & $-0.000 * * \quad(0.000)$ & $-0.000 * * *(0.000)$ \\
\hline cons & $-3.182 * * *(0.414)$ & $-2.990 * * *(0.540)$ & $-3.203 * * *(0.408)$ \\
\hline Number of obs & 87929 & 87929 & 87929 \\
\hline Wald chi2 & $1287.68 * * *$ & $1203.75^{* * *}$ & $1196.84 * * *$ \\
\hline Log pseudo likelihood & -21400.061 & -21391.285 & -21400.314 \\
\hline Pseudo R2 & 0.131 & 0.131 & 0.131 \\
\hline
\end{tabular}

Notes:

i. Robust standard errors in parentheses

ii. Significant at: †.10,*.05,**.01,***.001

iii. Std. Err. adjusted for 40 clusters in country_year

Finally, in model 10, we return to interactions between GDP per capita and institutions and run a specification where the interaction relates to our proxy of the size of the financial sector (Table 7). 
Table 7 - Determinants of Nascent Entrepreneurship (Startup). Logistic Regression. Model 10.

\begin{tabular}{|c|c|}
\hline & Model 10 \\
\hline dgender & $0.314 * * *(0.055)$ \\
\hline dumownmge & $1.152 * * *(0.114)$ \\
\hline dumbusang & $1.137 * * *(0.074)$ \\
\hline dumknowent & $0.921 * * *(0.064)$ \\
\hline dumgemwork & $0.305^{*} \quad(0.134)$ \\
\hline ed_postsec_high & $0.193 * * *(0.055)$ \\
\hline ed_high & $0.464+\quad(0.272)$ \\
\hline age & $0.016 \quad(0.022)$ \\
\hline age2 & $-0.000 \quad(0.000)$ \\
\hline pro_strong & $0.472 * \quad(0.215)$ \\
\hline credit_pri & $(0.006)$ \\
\hline gdp_pc_ppp & $-0.000 * * *(0.000)$ \\
\hline gdppc_cre & $(0.000)$ \\
\hline cons & $-2.854 * * *(0.527)$ \\
\hline Number of obs & 87929 \\
\hline Wald chi2(13) & $1224.38 * * *$ \\
\hline Log pseudo likelihood & -21363.825 \\
\hline Pseudo R2 & 0.132 \\
\hline \multicolumn{2}{|l|}{ Notes: } \\
\hline Robust st & Robust standard errors in parentheses \\
\hline Significan & Significant at: $\dagger .10, * .05, * * .01, * * * .001$ \\
\hline Std. Err. a & Std. Err. adjusted for 40 clusters in country_year \\
\hline Test that & $\begin{array}{l}\text { Std. Err. adjusted for } 40 \text { clusters in country_year } \\
\text { Test that coefficients for credit_pri and gdppc_cre are both zero: chi2 } 2=20.14^{* * *}\end{array}$ \\
\hline
\end{tabular}

We use logit and multiple logit as our estimators. Reported standard errors are robust (Sandwich) standard errors. We allow for the possibility that the observations are not independent for each country-year sample in our dataset and this is reflected in the estimated variance-covariance matrix and reported coefficients (apart from the specification where we apply the full set of sample country-year dummies instead).

\section{Discussion of Results}

Generally, the results are consistent with our priors. We discuss the details below.

\subsection{Results for Country Level Aggregate Institutional Variables}

Starting with legal origin dummies (model 3), we find that entrepreneurship is strongest in English origin countries, followed by German, French and Scandinavian origin (between which there are no significant differences) and finally weakest in the Socialist legal origin countries, confirming our hypothesis 3. 
Replacing the legal origin dummies with closely correlated index of economic freedom (which as we argued above should rather be seen as a composite index of economic freedom and institutional quality) we confirm our hypothesis 1: better institutions affect entrepreneurship positively (model 2). However, we obtain one additional interesting result: "Economic Freedom" has stronger impact on entrepreneurship in middle income and rich countries, but less so in poor countries. This is consistent with Klapper et al. (2006) findings for newly incorporated firms. High income countries are characterised by more complex technological and economic structures of production, where interdependence between the economic agents matters even more than in poor countries. This could explain the increasing significance of the quality of institutions in rich countries. The interactive term between the GDP per capita and institutional quality is strongly significant (and more significant than the individual terms). It is difficult to work out this joint impact of the three variables (GDP per capita, an institutional indicator and an interactive term), just from looking at coefficients, but based on both models 2 and 3 we calculated that at mean level of other variables, improved level of institutional quality results in more entrepreneurship. Interestingly, the effect becomes even stronger for developed countries. For poor countries, the institutions seem to matter less for entrepreneurship. We illustrate these effects with Figure 1 below.

Figure 1 - Impact of Economic Freedom on Entrepreneurship

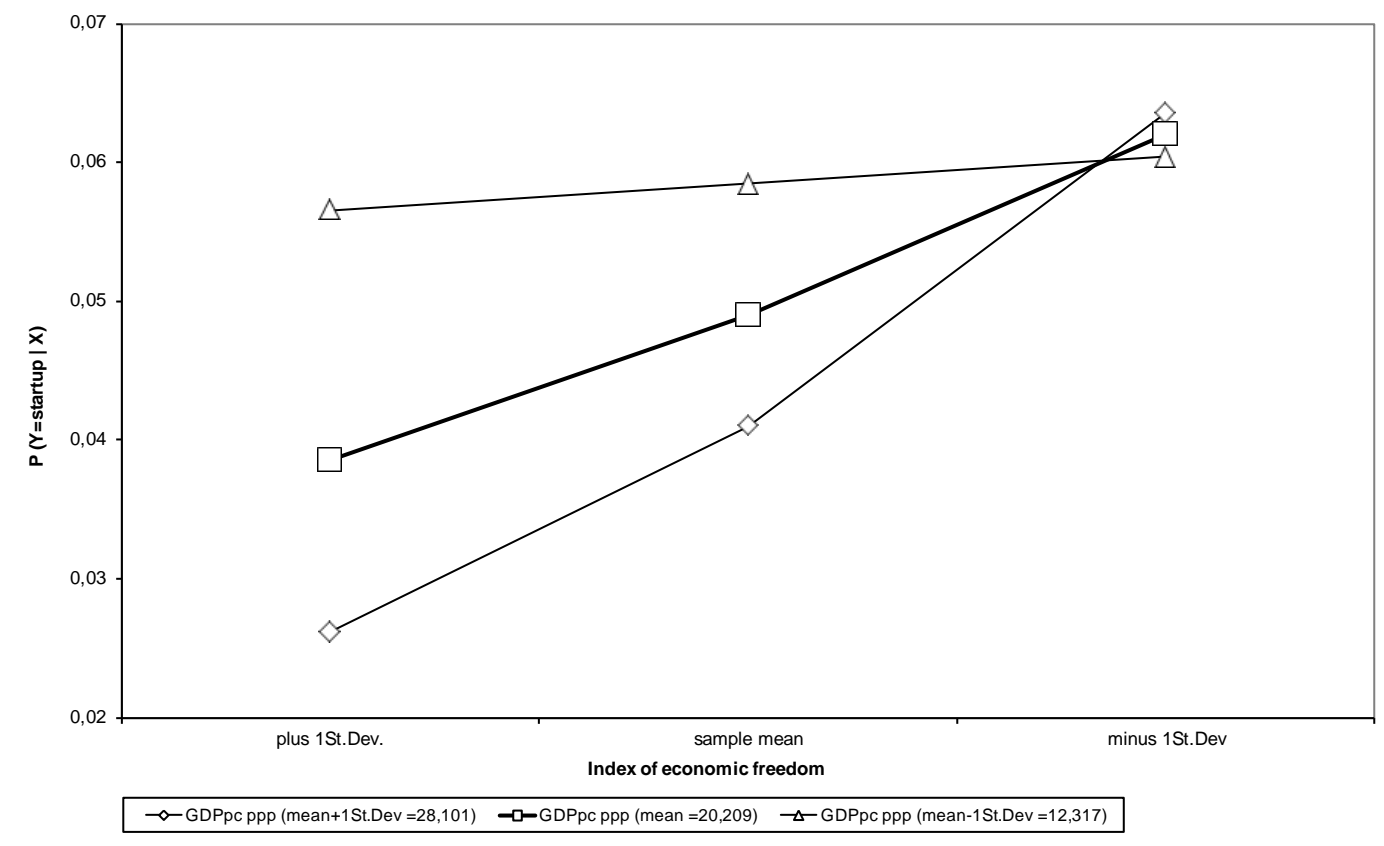


Corruption proves to be a more problematic indicator, mainly because it is strongly correlated with GDP per capita (correlation between the two variables is 0.85 ; which may be compared to a slightly lower correlation coefficient of corruption with the index of economic freedom: - 0.76). Therefore - as we control for GDP per capita - significant effects are more difficult to estimate. As a mean effect we find nevertheless that lower corruption is associated with more entrepreneurship. For the corruption index, in the case of less developed countries, the corresponding impact of institutions becomes marginally negative. One should not read too much from this, however. Joint impact of GDP per capita and institutions is only marginally significant ( $\mathrm{p}$-value $=0.0966$ ), while it is much more robust for the economic freedom measure ( $p$-value=0.0037).Thus, the latter should be trusted more in this context (results available on request).

An interesting novel result is that institutional quality ("Economic Freedom") affects 'opportunity' entrepreneurship more than 'necessity' entrepreneurship. This provides support for the hypothesis 4. Again, joint effects are not easy to calculate from coefficients reported in Table 5, but we illustrate them with Figure 2 below.

Figure 2 - Impact of Economic Freedom on Necessity versus Opportunity Start-ups

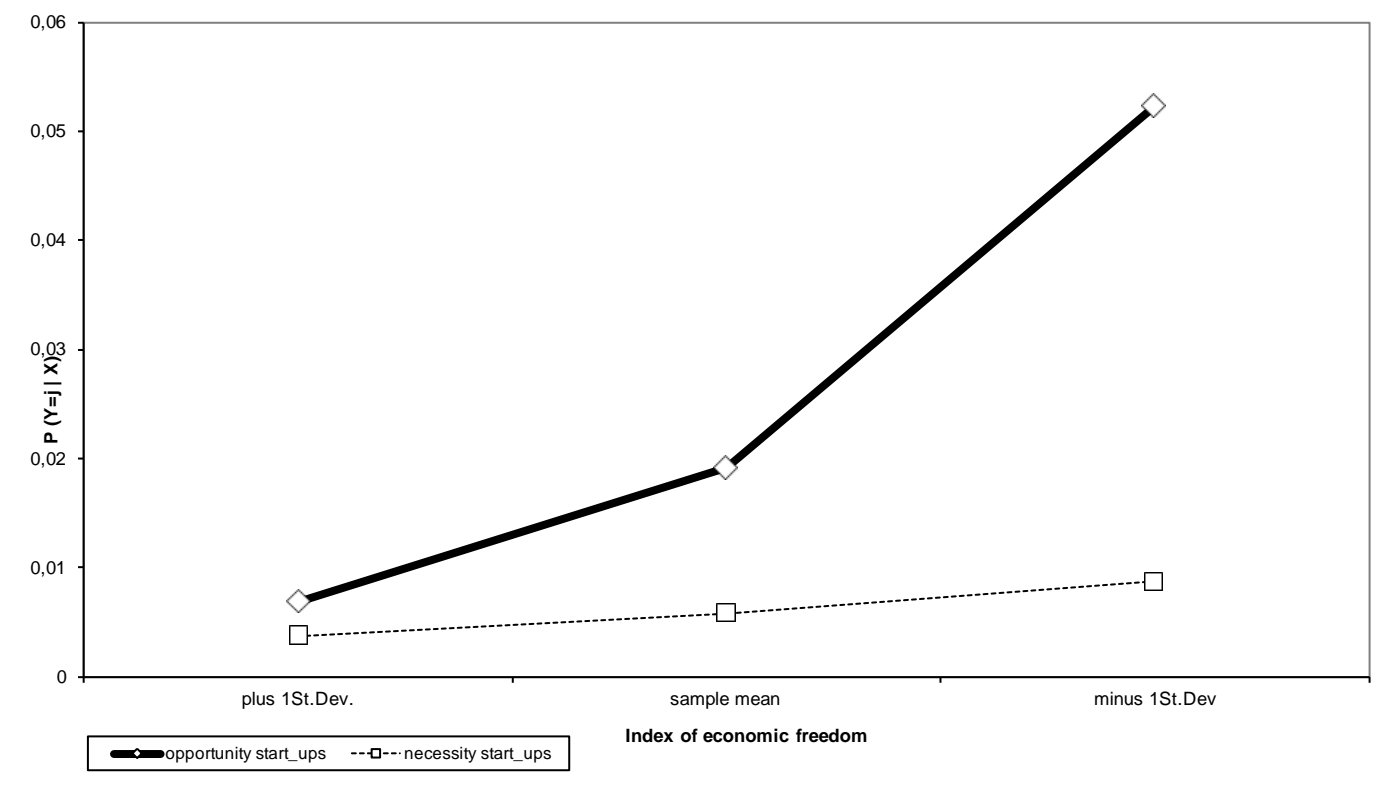

Our interpretation of that link is the following. Opportunity entrepreneurship is by definition associated with more significant gains from entry. Those gains imply incentives to develop and expand the new businesses. And it is where institutions may matter most. Potential entrepreneurs that expect their future expansion hampered by poor 
institutional environment may decide against entry, unlike in case of 'necessity' entrepreneurship.

Our key institutional results based on aggregate institutional indicators may be summarized as follow. Institutional quality ("Economic Freedom", a measure closely correlated with the concept of English legal origin) is clearly associated with more entrepreneurship, and the effect is strongest in developed countries. This is consistent with popular perceptions and consistent with Djankov et al. (2002), who found that the English legal origin is strongly associated with lowest barriers to entry.

Entrepreneurship seems to play an important role in development. In this narrow sense therefore, we could conclude that the English legal origin setting is 'superior'. However, there are clearly other institutional aspects that affect economic performance in different way. Japan, Germany, France, Scandinavian countries and others represent different legal traditions which were equally successful in the long-term process of the economic development. Clearly, in this wider perspective, their deficiency with respect to entrepreneurship must be counter-balanced by some other institutional advantages, which is an issue going beyond the scope of this paper.

\subsection{Multiple Institutional Indicators}

Two institutional indicators emerge as robust from various specifications based on the combinations of five institutional indices discussed above. These are: strong protection of property rights and the size of the private sector financing (models 7-10). This result provides support for hypothesis 2 . Both come with positive sign, and clearly affect the scope of entrepreneurship significantly. Next, inflation and the economic size of the government come with expected (negative) signs but are insignificant in multivariate specifications, and their effects remain dominated by the first two dimensions. Finally, marginal tax rates remain consistently insignificant (and come with unexpected positive signs).

Given the significance of the scope of finance, we also explore the results of interaction of this variable with the level of GDP per capita. Interestingly, the pattern of impact of finance on entrepreneurship remains similar for different level of development. This is in contrast to the economic freedom indicator, which has far stronger impact for rich countries. We illustrate the effects of this interaction with Figure 3 below. 
Figure 3 - Impact of Credit/GDP on Entrepreneurship

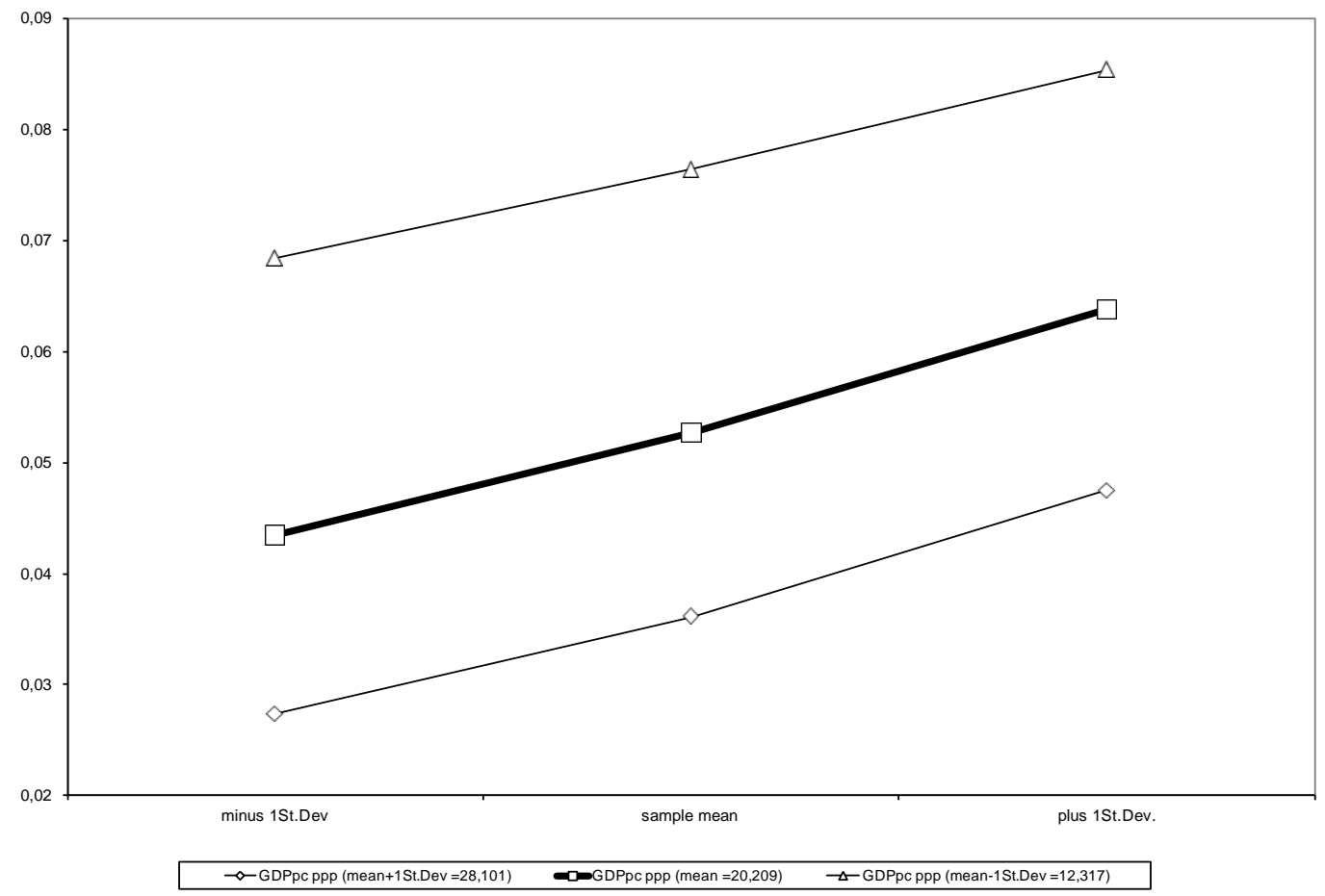

\section{Conclusions}

Strong protection of property rights plays a pivotal role in the institutional environment. This is a single dimension, which dominates all other institutional variables when we compress the data into a smaller number of dimensions using factor analysis. We confirm that strong protection of property rights affects entrepreneurial entry positively. The second important institutional factor relates to the extent of the financial sector, in line with the existing literature. Moreover, we find that the impact of institutions varies at different levels of economic development. Entrepreneurial entry in a sophisticated, high income economy is more dependent on quality of institutions than in a poor country.

The effect of institutions on entrepreneurial development is a fruitful area for further research. Though the GEM data used set containing 31 different countries offers excellent uniform data for cross-country comparisons, there is a sample selection bias. To date, there are not many participating countries that have very weak institutions nor are there small poor countries in the sample. It would be interesting to add this data as it becomes available. It would also be useful to include other institutional indicators as they are developed and refined.

Our findings have implications for policy makers. Developing a stronger institutional environment can have a positive effect on 
entrepreneurship development, especially opportunity entrepreneurship. Of specific importance is the protection of property rights and a strong financial sector. But it is also important to note that though laws can change quickly, the more fundamental and lasting change to the institutional environment takes time as is exemplified by the generally slower rate of entrepreneurship development in the post-Socialist countries in Central and Eastern Europe. 


\section{References}

Acs, Z., Audretsch D., \& Evans D. (1994). Why Does the Self-employment Rate Vary across Countries and over Time? CEPR Discussion paper, 871.

Acs, Z., Arenius, P., Hay, M., \& Minniti M. (2004). Global Entrepreneurship Monitor 2004 Executive Report, Babson College, MA, US and London Business School, UK, http:/ / www.gemconsortium.org.

Aidis, R., Estrin, S., \& Mickiewicz, T. (2007). Entrepreneurship, Institutions and the Level of Development. Tiger Working Paper Series, 103.

Aidis, R., \& Mickiewicz T. (2006). Entrepreneurs, Expectations and Business Expansion: Lessons from Lithuania. Europe Asia Studies, 58 (6), 855-880. doi:10.1080/09668130600830961

Barkhatova, N. (2000). Russian Small Business, Authorities and the State. Europe-Asia Studies, 52 (4), 657-676. doi:10.1080/713663075

Baumol, W. (1990). Entrepreneurship: Productive, Unproductive, and Destructive. Journal of Political Economy, 98 (5), 893-921. doi:10.1086/261712

Beach, W., \& Miles M. (2006). Explaining the Factors of the Index of Economic Freedom. Chapter 5 in Heritage Foundation's Index of Economic Freedom 2006, http:/ / www.heritagefoudation.org

Berkovitz, D., \& Jackson J. (2006). Entrepreneurship and the Evolution of Income Distribution in Poland \& Russia. Journal of Comparative Economics, 34 (2), 338-356.

Carree, M., van Stel, A., Thurik R., \& Wennekers, S. (2002). Economic Development and Business Ownership: An analysis using data of 23 OECD countries in the period 1976-1996. Small Business Economics, 19 (3), 271-290. doi:10.1023/A:1019604426387

Davidsson, P., \& Honig, B. (2003). The Role of Social and Human Capital Among Nascent Entrepreneurs. Journal of Business Venturing, 13 (3), 301331. doi:10.1016/S0883-9026(02)00097-6

Delmar, F., \& Davidsson, P. (2000). Where Do They Come from? Prevalence and Characteristics of Nascent Entrepreneurs. Entrepreneurship and Regional Development, 12 (1), 1-23. doi: $10.1080 / 089856200283063$

Desai, M., Gompers, P., \& Lerner, J. (2003). Institutions, Capital Constraints and Entrepreneurial Firm Dynamics: Evidence from Europe. Harvard Negotiation, Organizations and Markets Research Papers, 03-59. 
Djankov, S., La Porta, R., Lopez-de-Silanes, F., \& Shleifer, A. (2002). The Regulation of Entry. Quarterly Journal of Economics, 107 (1), 1-37. doi:10.1162/003355302753399436

Evans, D., \& Jovanovic, B. (1989). An Estimated Model of Entrepreneurial Choice under Liquidity Constraints. Journal of Political Economy, 97 (4), 808-827. doi:10.1086/261629

Evans, D., \& Leighton, L. (1989). Some Empirical Aspects of Entrepreneurship. American Economic Review, 79 (3), 519-535.

Glaeser, E., Scheinkman, J., \& Shleifer, A. (2003). Injustice of Inequality. Journal of Monetary Economics, 50 (1), 199-222. doi:10.1016/S03043932(02)00204-0

Grilo, I., \& Irigoyen, J. (2006). Entrepreneurship in the EU: to Wish and not to Be. Small Business Economics, 26 (4), 305-318. doi:10.1007/s11187-005$\underline{1561-3}$

Grilo, I., \& Thurik, R. (2005). Latent and Actual Entrepreneurship in Europe and the US. International Entrepreneurship and Management Journal, 1 (4), 441-459. doi:10.1007/s11365-005-4772-9

Hirschman, A. (1958). The Strategy of Economic Development. New Haven: Yale University Press.

Johnson, S., Kaufmann, D., \& Shleifer, A. (1997). Politics and Entrepreneurship in Transition Economies. William Davidson Institute Working Paper, 57.

Johnson, S., McMillan, J., \& Woodruff, C. (2002). Property Rights and Finance. American Economic Review, 92 (2), 1335-1356. doi: $10.1257 / 000282802762024539$

Klapper, L. , Laeven, L., \& Rajan, R. (2006). Entry Regulation as a Barrier to Entrepreneurship. Journal of Financial Economics, 82 (3), 591-629. doi:10.1016/j.jfineco.2005.09.006

Krueger, N., Reilly, M., \& Carsrud, A. (2000). Competing Models of Entrepreneurial Intentions. Journal of Business Venturing, 15 (5-6), 411432. doi:10.1016/S0883-9026(98)00033-0

Lambsdorff, J. (2005). Methodology of the 2005 Corruption Perceptions Index. Mimeo. Transparency International and University of Passau.

La Porta R., Lopez-de-Silanes, F., Shleifer, A., \& Vishny R. (1999). The Quality of Government. Journal of Law, Economics and Organisation, 15 (1), 222-279. doi:10.1093/jleo/15.1.222

Levesque, M., \& Minniti, M. (2006). The Effect of Aging on Entrepreneurial Behavior. Journal of Business Venturing, 21 (2), 177-194. doi:10.1016/j.jbusvent.2005.04.003 
Lumpkin, G., \& Dess, G. (1996). Clarifying the Entrepreneurial Orientation Construct and Linking it to Performance. Academy of Management Review, 21 (1), 135-172. doi:10.2307/258632

McMillan, J., \& Woodruff, C., (2002). The Central Role of Entrepreneurs in Transition Economies. Journal of Economic Perspectives, 16 (3), 153-170. doi:10.1257/089533002760278767

McMullen, J., \& Shepherd, D. (2006). Entrepreneurial Action and the Role of Uncertainty in the Theory of the Entrepreneur. Academy of Management Review, 31 (1), 132-152. doi:10.2307/20159189

Megginson, W., \& Netter, J. (2001). From State to Market: A Survey of Empirical Studies on Privatisation. Journal of Economic Literature, 39 (2), 321-389.

Mickiewicz, T., Gerry, C., \& Bishop, K. (2005). Privatisation, Corporate Control and Employment Growth: Evidence from a Panel of Large Polish Firms, 1996-2002. Economic Systems, 29 (1), 98-119. doi:10.1016/j.ecosys.2005.02.002

Minniti, M. (2005). Entrepreneurship and Network Externalities. Journal of Economic Behavior and Organization, 57 (1), 1-27. doi:10.1016/j.jebo.2004.10.002

Minniti, M., Arenius, P., \& Langowitz, N. (2005a). GEM 2004 Report on Women and Entrepreneurship, http:/ / www.gemconsortium.org.

Minniti, M., Bygrave, D., \& Autio, E. (2005b). Global Entrepreneurship Monitor. 2005 Executive Report, Babson College, MA, US and London Business School, UK, http:/ / www.gemconsortium.org.

North, D. (1990). Institutions, Institutional Change and Economic Performance. New York: Cambridge University Press.

Parker, S. (2006). New Agendas in the Economics of Entrepreneurship: Optimism, Education, Wealth and Entrepreneurship. Paper presented at the ASSA - American Economic Association Annual Conference. Boston, USA.

Pryor, F. (2006). Economic Systems of Developing Nations. Comparative Economic Studies, 48, 77-99. doi:10.1057/palgrave.ces.8100072

Sarasvathy, S. (2004). The Questions We Ask and the Questions We Care about: Reformulating Some Problems in Entrepreneurship Research. Journal of Business Venturing, 19 (5), 707-717. doi:10.1016/j.jbusvent.2003.09.006

Schaffer, M., Carlin, W., \& Seabright, P. (2006). Where Are the Real Bottlenecks? A Lagrangian Approach to Identifying Constraints on Growth from Subjective Data. Paper presented at the Centre for Economic 
Development and Institutions inaugural conference. University of Brunel, UK.

Shane, S., \& Venkataraman, S. (2000). The promise of Entrepreneurship as a Field of Research. Academy if Management Review, 25 (1), 217-226.

Storey, D. (1994). Understanding the Small Business Sector. London: International Thomson Business Press.

Tanzi, V. (1998). Corruption Around the World. IMF Staff Papers, 45 (4), 559-594.

Verheul, I., van Stel, A., \& Thurik, R. (2006). Explaining Female and Male Entrepreneurship at the Country level. Entrepreneurship and Regional Development, 18 (2), 151-183. doi:10.1080/08985620500532053

Wennekers, S., van Stel, A., Thurik, R., \& Reynolds, P. (2005). Nascent Entrepreneurship and the Level of Economic Development. Small Business Economics, 24 (3), 293-309. doi:10.1007/s11187-005-1994-8 